\title{
Religious Practices as Stress Management Among Young Muslims in Indonesia
}

\author{
Yufi Adriani ${ }^{1}$ and Desi Yustari ${ }^{1}$ \\ \{yufi.adriani@uinjkt.ac.id ${ }^{1}$,desi.yustari@uinjkt.ac.id ${ }^{1}$ \} \\ Faculty of Psychology, UIN Syarif Hidayatullah Jakarta ${ }^{1}$
}

\begin{abstract}
This research explored the religious practices as stress management among young Indonesian Muslims. The aim of the study was to explain how religiosity as experienced understood by a group of 12 young people studying at a large public Islamic university in Jakarta and could be managed them stress well. Interviews with the participants about their religious practices and stress management were analysed. Findings showed that religion played a role in the way the study participants managed stress. All of them had experienced stress deriving from different areas of their life. Some of them felt that religion could help them to overcome such stress and reported using the religious practice to address stress, even though this approach tended not to occur to them until after they had already experienced the stressful event. Sources of stress reported by the participants in this study generally related to their university studies and relationships with family and friends, including romantic relationships
\end{abstract}

Keywords: Religious, Stress management, Young Muslims, Indonesia

\section{Introduction}

Indonesia is the world's biggest Muslim nation in terms of inhabitants. But, Islam is not the religion of the state. In fact, the Indonesian government has acknowledged five religions, which are Islam, Protestantism, Catholicism, Hinduism, and Buddhism; other beliefs, which incorporate conventional animist and nature religions, are also acknowledged but are sorted together. Confucianism is presently recognized too. Adherence to religion is expected in Indonesia, at least formally, and expression of Islam, as the majority religion adhered to by more than $80 \%$ of the population, is visible in a range of public and private contexts.

Lippman and McLintosh (2010), who surveyed religiosity and spirituality among youth around the world that included Indonesia, concluded that $75 \%$ of the nation's young adults believe in God and say that religion plays a very important part in their life. This is likely because of the solid position that religion holds in general society and private circles and its focal position in a considerable lot of Indonesia's neighbourhood societies. For instance, some of Indonesia's ethnic gatherings express that adherence to Islam is construed normally for gathering participation. In these societies, it isn't feasible for an individual to belief in another religion and still be viewed as a part of the group since its membership is based on being Muslim [1].

Indonesian Islam has some differences as is rehearsed in the Middle East and somewhere else in Asia. Religion in general in Indonesia is often said to be syncretic [2], referring to the mixing of various traditions that have taken place through the region's history. In practice, this implies numerous individuals hold convictions that originate from an antiquated period before 
outside religions, including Islam, were existent in Indonesia. A considerable lot of these syncretic beliefs can be categorized as enchantment or superstition and are not considered to be in conflict with the more formalized beliefs of Islam or Christianity.

Islam has what is called as "Five Pillars of Islam" that represent five religious obligations for individuals who claimed themselves as Muslims. The Five Pillar of Islam consists of: declaration of faith, obligatory prayer, obligatory giving of alms (zakat), obligatory fasting during the month of Ramadhan, and pilgrimage to Mecca (hajj). While these five activities portray the basics of religious observance around the world, the way by which they are done may has some differences from one place onto the next. In Indonesia, specifically, culture and demographic factors impacts the way people practice religion. It is possible to be influenced by the origins of Islam in Indonesia when nine preachers who were fundamental in spreading Islamic teachings adopted the traditional dress and used traditional songs to familiarize the public with the new religion [3]. This attempt to fit the religion into existing cultural practices can be seen as a syncretic force intended to make a new belief system to be more compatible with thencurrent practices.

Indonesian Muslims are also often to be considered as moderate. A concrete example of this can be seen in the terms used to refer to religious concepts. For example, the common name in Indonesian for the five daily prayers of Islam is sembahyang, which is often used in preference to shalat, which originates from Arabic. Sembahyang comes from a Sanskrit root and can also be applied to other prayers in any religion (Islam, Christianity, Balinese Hinduism, etc.) (Depdiknas, 2014). The original Indic concept of sembahyang was expanded to include new forms of prayer associated with later religions as they were adopted in Indonesia. Other examples can be found in language, such as the use of the term langgar to refer to a mosque. Langgar is a Malay root that exists parallel to the term masjid, which comes from Arabic [4]. A number of Arabic terms are used to refer to specifically Islamic practices, even though many of these are carried out in a way that reflects Indonesian traditions, not those of the Arab world. This circumstance has contributed to widespread observations that Indonesia Muslims tends to be moderate and flexible.

These characteristics of Indonesian Islam can be found in a range of cultural practices that incorporate Islamic beliefs with other kinds of cultural practices, regularly involving some form of mysticism. Indonesian Muslims tend to believe strongly in the value of prayer or doa. Many feel that this type of prayer can help people to gain inner peace [5] yet in addition that it can cure people of any kind of illness. Consequently, Indonesian Muslims have specific doa for each kind of ailment [6]. This practice has elements of an older belief framework where specific gods or supernatural entities were called upon for various kinds of assistance they were felt to have the capacity to address.

Furthermore, in many parts of Indonesia, various kinds of non-Islamic activities have become associated with an Islamic practice to the point where a prominent number of people see them as having the same status. For instance, many Indonesians hold a ceremony for women in the seventh month of pregnancy that is intended to guarantee that the mother and child are blessed by God. While the Quran may be read at the ceremony, the timing and ceremony itself are not related to Islam as it is practiced elsewhere in the world, and in fact comes from indigenous cultural practices that essentially originate before Islam exist in Indonesia [7]. Similar rituals that come from indigenous traditions but have been given an Islamic element are often held to give thanks to ensuring the success of important events, such as for people about to go on the hajj, to encourage rain after a period of drought, and so forth [8]. Besides incorporating Islamic elements into cultural rituals, there is another unique characteristic of Indonesian Muslims, which is the importance of the idea of takdir or fate. 
Takdir explicitly alludes to the concept that each person has a lot in life that has been determined by God and must be accepted because there is no possible thing to do to change to them (Von Vacano and Schwarz, 2014). A faith in this sort of fate has been suggested to act as a source of resilience for many Indonesians, even in times of extreme stress, because it allows them to accept their experience with a certainty that God would not subject them to something they could not stand and, if they or another person dies or suffers some other kind of misfortune, it was a necessary and unavoidable thing and must be approached with resignation and acceptance. Consequently, belief in takdir allows many Indonesians to feel happy and content, even under very extreme circumstances [9]. Nonetheless, a number of observers have noted that the situation in Indonesia seems to have changed over the period since the end of the New Order government. The first years of the 2000s have been characterized by the emergence of Islam as an important social trend in the public environment, as opposed to a more personal aspect of people's experience. It is not clear whether this represents a change in people's beliefs or whether there is some other reason for the change, but it is the case that Islam is currently more prominent as a social force than it has been in the past. The time of reformasi [reform] which happened after the renunciation of President Suharto in 1998 was (the end of New Order Government) characterized by financial unsteadiness and social turmoil. These issues eventually settled, yet the political and social circumstance in Indonesia has remained extremely dynamic. This is a significant contrast with the Suharto era, which was characterized by high levels of social and economic stability maintained through the government period [10]. Among the many changes to the political system since the end of the New Order has been the emergence of a large number of political parties, a few of which are Islamic parties. It has been suggested that this is a reaction to a sort of moral degeneration perceived by some members of the public as well as the political elite [11].

Regardless, the importance of Islamic practices in the public sector has, by all accounts, expanding [12].. For instance, these recent years have seen a widespread move to Islamic dress among Indonesian women. Many women who did not dress in an Islamic manner in the 1990 s changed to a more Islamic style that included a hijab in the 2000s. While some Indonesians have interpreted this change as a desire by women to empower themselves and address the perceived lack of morality in the public context, it is also possible to see the change in dress as another reflection of ethnic and/or cultural identity or a desire of individuals to associate themselves with a source of prestige. Regardless of the underlying motive, anecdotal evidence suggests that the change in dress convention has a strong aspect of social pressure as Indonesian society is highly conformist and people generally do not like to be different from the majority in any way that is readily observable [13].

Another manifestation of Islam in the public sphere is the abrupt popularity of syariah banking. Banking services that accord with Islamic principles interest were not popular in Indonesia during the New Order, although one Islamic bank did exist at the time. At present, by contrast, virtually every bank offers syariah services and products [14]. While this might be viewed as manifestation of Islamic incilination among the Indonesian public, it is worth noting that the Asian economic crisis of 1997-1998 that led directly to the resignation of President Suharto was accompanied by a collapse of the banking system, which severely harmed public's trust in these institutions. The rise of syariah banking may also be seen as a reaction to any doubts in regular banks and an aspect of the same identity movement that has led to widespread regionalism and favoritism in the public environment (see Republika, 2013).

The fact that Indonesia is not authoritatively a Muslim country and acknowledge a number of religions in its national philosophy, yet the interests of the enormous Muslim population have dictated government policy in a number of areas. For instance, in the month 
of Ramadhan, when Muslims are supposed to fast during daylight hours, the operation of entertainment venues, such as bars, night and karaoke clubs, has been limited by law [15]. The official aim of such policies is to support members of the public in participating in the tarawih prayers held at night during the fasting month. Similar rulings in various parts of the country, which is limiting the time operation of restaurants during daylight hours when Muslims are supposed to be fasting and require those that do remain open to cover their windows so that people who are fasting do not have to see others, which are not, enjoying their meals [16][17].

While it is quite easy to see manifestations of Islamic principles in the public environment in Indonesia, it is significantly harder to explain what individuals believe. Up to the present time, Indonesia has been comparatively free of radical activity, regardless of several terrorist bombings in the early 2000s that were associated with Islamic groups. There has been little support at the national level for syariah law, although such a measure has occasionally been proposed, and the province of Aceh has implemented syariah as part of its special autonomy arrangements [18]. Nonetheless, the impact of Islamic principles and practices on individuals is significant and may direct a range of personal behavior. There is also assemblage of society that is known and recognized by many individuals that envelops a belief in supernatural creatures, magic, traditional healing practices, folklore relating to the prophet Muhammad and other religious figures, and a range of other phenomena not directly related to Islam as it is practiced in the Middle East or elsewhere in the world [19]. These aspects of religious belief, which are closely related to the individual's cognitive and affective perceptions, contrast with the formal expression of Islam, which largely takes the form of ritualized practice whose outward form may be most significant [20]. Nonetheless, it should be noted that participation in these rituals maybe a source of happiness or satisfaction for some Indonesians, in addition to any other impacts that come from their beliefs.

The Indonesian population is comprised of people from a wide range of ethnic groups that embraced various religions at different points in history, and Islam is one of six formally recognized religions. The religion exists alongside a pre-existing culture. Nonetheless, most Indonesians, as well as western observers, agreed that religion is an important social force in Indonesia, and there is some evidence to show that Islam has become more prominent in the last decade as an aspect of the social environment. For this reason, in order to better understand Indonesian society and the perceptions of Indonesians about their life and experience, an understanding of the relationship between religion and happiness is vital and will provide important information that can support a range of social and health initiatives.

\section{Methods}

This study used a phenomenological approach that allows for an in-depth exploration of the personal experience of the young people involved. The method outlined by Giorgi, which has the benefit of allowing a comparatively unknown phenomenon to get across. This study, then, is descriptive and allows for the utilization of Husserl's concepts of intentionality and phenomenological reduction. In doing so, it keeps up both, reliability to the lived experience of the individuals involved and furthermore comprised an analysis of this experience in the sociocultural context where it occurred.

This method involved semi-structured interviews with 12 young adults aged 18-24, university students in Jakarta. Seven men and five women were recruited from the of Universitas Islam Negeri (UIN) Syarif Hidayatullah Jakarta (Syarif Hidayatullah State Islamic 
University of Jakarta) by advertisement. All those who responded were screened by the researcher to verify their fitness to the profile for participants. All participants in this study were Muslim and were currently enrolled in an undergraduate degree in various fields, with the exception of psychology. Reason why Psychology students were excluded from this study was because they might have known the researcher, who is a member of University staff in Psychology, which might have impacted their responses. These participants were interviewed and encouraged to talk in detail concerning their views of religion, the value of religious practice and its role in their life, the things that make them happy, and the extent to which they consider them as being associated. Each interview took approximately one hour and was recorded in audio format to ensure reliability. No restrictions were placed on participants in terms of how the open-ended questions that made up the interview should be interpreted or on the type of responses they were expected to give.

In addition to being recorded, the researcher took notes that include impressions of the participant's manner, specific terminology used, code switching between languages if observed, and other aspects of behavior that were not evident from the recordings. The interviews were transcribed, de-identified and saved on the researcher's personal computer in password-protected files. Following transcription, phenomenological descriptive analysis using the methodology developed by Giorgi [21] was carried out in order to create a nuanced description of the participants' experience that contains the meaning they ascribe to their experience and their interpretation of the larger concept of religiosity.The interviews for this study were conducted in Indonesian. A number of excerpts were translated by the author into colloquial English. The use of languages other than Indonesian (Arabic, English, Indonesian local languages) are indicated. All translations were checked by the experts, who is fluent in Indonesian and is a native speaker of English.

\section{Religious Practices as Stress Management}

The relationship between religion and happiness can be direct or indirect. One of the factors that will contribute to this relationship is the coping strategy available to the individual. Coping strategies consists of various methods that people regularly use to overcome stressful events in their lives and furthermore to manage distress that is associated with them.

In young adulthood, five dimensions have been proved related to stressful experience: life traumas, life events, chronic strain, major discrimination, and day-to-day discrimination [22]. Young people's coping strategies can be various, based on the individual's personality, environmental context, and the parenting style used by their caregivers [23]. Coping strategies are necessary to deal with uncomfortable situations and any related stress. Stress is any specific situation that might involve harm (in a psychological sense) or loss and challenges (Lazarus and Folkman, 1984). Stress may also be caused by horrendous incidents or personal life events (divorce, job loss, chronic illness, physical violence, poverty, sexual harassment, caregiving, etc.). A range of coping strategies is available in every situation, but individuals will pick a strategy that fits their personality and that is accessible at the time, which is the existence of cognitive and affective resources to use.

Lazarus and Folkman (1984) identify two different types of coping strategies. The first is problem-focused coping, which refers to a person's effort to modify or change the stressor itself, such as searching a solution to the problem, asking for advice from others, or making a plan to approach the problem. The second is emotion-focused coping, in which the 
individual attempts to accommodate to the stressor in order to reduce emotional distress. Examples of this second type of strategy include distraction, avoidance and denial as well as talking about the problem, accepting the problem, and focusing on the positive side. NolenHoeksema, Parker and Larson [24] suggest that rumination is also a coping strategy. Rumination, which involves thinking about the problem, may result in an overly deep focus on the problem, which may interfere with effective coping. However, if rumination involves discussing the problem with another person, coping may be more effective.

Aspects of coping can be divided into two groups that can be viewed as approach strategies, that include problem solving and seeking social and emotional support, and avoidance strategies, such as denial, distraction, blame, behavioral engagement, and substance use. While avoidance strategies can be considered maladaptive ways to overcome stress, approach strategies are generally seen as adaptive [25].

Religious coping, which possibly involve attending formal religious services, reading religious texts, praying, and so forth, is considered an important form of positive coping strategy. Religious coping is individual response by involving God to deal with adversity and finding a solution. The indicator of religious coping consist of working collaboratively with God, seeking God's love and care, seeking spiritual support from others, and reappraising a situation in a magnanimous way [26]. This is positive religious coping, which is associated with strong faith in God. On the other side, it can also be the case that people hold God accountable for their problems, which is called negative religious coping. This type of negative coping may be observed in people who think that God should not let bad things happen to people who believe in Him, and may interpret negative experience to mean that nothing good can happen out of problems. Pargament [27] concludes that positive religious coping strategies are related to self-esteem, life satisfaction and quality of life. On the contrary, negative religious coping tends to be associated with more depressive symptoms.

Pargament et al. [28] identify several forms of both positive and negative religious coping. The positive strategies include: (1) religious purification/forgiveness; (2) religious direction/conversion; (3) religious helping; (4) seeking support from other members; (5) collaborative religious coping; (6) religious focus; (7) active religious surrender; (8) benevolent religious reappraisal; (9) spiritual connection; and (10) marking religious boundaries. The negative strategies include: (1) spiritual discontent; (2) demonic reappraisal; (3) passive religious deferral; (4) interpersonal religious discontent; (5) reappraisal of God's powers; and (6) pleading for direct intercession. These are useful categories of behavior that can help to identify actions that may be associated with religious belief and help to understand how an individual applies his/her religious interpretations to experience and may have predictive value. They also represent categories that can be applied in analyzing a person's past reactions to events and contribute to an overall assessment of religious feeling.

$\mathrm{Wu}$ and Liu (2014) argued that positive religious coping has many benefits and furthermore can improve mental health. This type of coping can lead to positive emotions, inner peace, comfort, higher self- esteem, forgiveness, kindness and altruism. Additionally, religious coping activities include private religious acts such as prayer or reading a holy book and also public religious activities that include participating in organized activities, performing religious rituals, or doing social work and helping others. People often fall back on these religious coping strategies when they have negative experiences; their religious feelings may not be evident under other circumstances when coping is not required [29].

Studies also show that religion is one of the individual factors that seems to contribute to positive emotion. It shows that individual with strong religious beliefs may be happier than others for a number of reasons. This issue has been given serious consideration 
within the field of psychology. First, religion may help and support people in ascribing meaning to life and believing that good things will happen in the future (Seligman, 2002). Individuals may gain confidence in managing stressful situations because they believe that the stressful event is a part of God's plan and can see it as a positive opportunity to gain wisdom and achieve personal maturation [30]. Second, involvement in routine attendance at religious services and being part of a religious community provides people with social support, which in turn may make people happier as well. People who feel a close proximity to God tend to be happier compared to people who don't believe in God (see Rosmarin, et al., 2009).

Several empirical investigations have found positive correlations between religiousness and happiness, and this is typically seen as proof of the universal advantageous of religion. While interest in the relationship between religion and happiness has been great and can be seen as part of the concern with positive psychology, the results of scholarship in this area have been disputable. A number of studies have shown a consistent positive relationship [31][32][33][34][35][36]. Other studies have not shown this type of result $[37][38][39][40][41][42]$.

These studies made use of a range of measures and approaches and, as a result, their findings are difficult to compare. In an attempt to resolve this problem, Lewis and Cruise [43] reviewed two sets of studies that were undertaken in a rigorous manner using the widely accepted Francis Scale of Attitude toward Christianity [44] and the Oxford Happiness Inventory [45]. A second set of studies used the Francis Scale and the Depression-Happiness Scale [46]. An analysis by Lewis and Cruise [47] indicated that eight of nine studies using the Francis Scale of Attitude toward Christianity, which is seen as a measure of religiosity, and the Oxford Happiness Inventory found a positive association, while one showed no association. Of five studies that use the Francis Scale and the Depression-Happiness Scale, four found no association between religion and happiness. Lewis and Cruise further noted that the finding of no association is consistent with other work that attempted to operationalize the definition of religiosity [48][49].

In evaluating the work on the relationship between religion and happiness, Lewis and Cruise [50] noted that there are some inconsistencies between studies, such as the difference method used in those studies. They also suggest that crosssectional research has been used to many times and heavily rely upon, yet the findings from this work may be limited in application. They also recognize a need for other types of study design and also for consideration of factors that may mediate both religiosity and happiness. The difficulty in operationalizing relevant concepts and identifying measures that will accurately capture the experience of individuals and the nature of the phenomena of interest is a recognized problem in the study of religiosity and happiness. Part of this difficulty is a result of the highly personal nature of experience and the impact of personality on perception. For this reason, this study takes a phenomenological approach that will allow for the elucidation of individual interpretation and understanding among young people in Indonesia. It is expected that this will provide insight into the nature of happiness in the context of Indonesian Islam and will give a better understanding of happiness as a universal human experience.

\section{Discussion}

The participants in this study face many of the stressors usually related with their age, which consists of, concern about future employment, relationships with family and friends, 
romantic problems, problems in their studies, and so forth. Life in Indonesia's capital is very difficult as well; extremely high population density is associated with extreme traffic problems, environmental degradation, high cost of living, intense competition for opportunities, and other issues that characterize major cities in Asia [51]. Several participants described the things that upset them as follows:

"Kuliah . . tidak bisa melupakan hubungan pacaran masa lalunya yang telah berjalan cukup lama namun karena agama melarang dan pasangannya pergi begitu saja. . . kalau teringat suka stres."

[(Even though) I was going to class, I couldn't forget my relationship with my old boyfriend that went on for a long time. Religion forbade it, and he left me just like that. Whenever I think about it. It makes me stressed.]

Participant 4

Deadline tugas, banyak tugas kuliah yang deadlinenya bersamaan, sulit membagi waktu antara kuliah dan organisasi."

[I have assignment deadlines, all my assignments are due at the same time, and it's hard to divide my time between my classes and my organization.]

\section{Participant 10}

"Ketika dimarahi orangtua, masih banyak mata kuliah yang belum diambil... Merasa hanya dirinya saja yang sering dimarahi, kedua adiknya tidak pernah dimarahi."

[When my parents are mad at me (because of) all the classes I still have to take, I feel like it's only me they are angry with. They are never mad at my two younger brothers.]

\section{Participant 12}

For some of the participants in this study, religion helps them to take the edge off their problems. For those individuals, it also seemed to support resilience and help them overcome with negative events, for example:

"Upaya untuk mengatasi stres biasanya menceritakan semua masalahnya kepada orangtua. Lalu wudhu, sholat dan membaca Al Quran sampai akhirnya lupa masalahnya."

[I usually try to overcome stress by telling all my problems to my parents. Then I do wudhu [ritual washing before praying], pray, and read the Quran until I forget what was bothering me.]

\section{Participant 4}

"Terlalu banyak hal yang harus dikerjakan, cara mengatasi mendengarkan orang mengaji dan melihat drama Korea. Agama bisa membantu mengatasi stres." 
[(If I have) too many things to do, I manage by listening to (a recording of) someone reciting the Quran and by watching Korean drama series. Religion can help overcome stress.]

\section{Participant 5}

"Cara mengatasi stress dengan menyendiri dan menarik diri dari lingkungan untuk sementara, ibadah atau berdiam diri di masjid."

[I deal with stress by going off by myself and withdrawing from things for a while, (then) I pray or meditate at the mosque.]

\section{Participant 7}

"Ketika ada masalah atau beban dan kita dituntut untuk segera menyelesaikannya dan selama ini cara mengatasinya dengan mengaji dan beribadah."

[When I have a problem or burden and have to deal with it right away, I have always coped by reciting the Quran and praying.

\section{Participant 8}

"Agama membawa kepada ketentraman jiwa."

[Religion gives you serenity.]

Participant 3

Some of the participants felt that religion could be used as a means to cope with stress, but other participants specifically stated that religion was not much help in dealing with their problems. They preferred to do activities those unrelated to religious practices. These participants based their answers on their experience that had showed them that religion did not provide enough support. Some of them commented that they used to pray, fast and give alms, but these activities did not suggest a solution to their problems or help them manage their emotions. The participants described this as follows:

"Untuk mengatasinya berusaha untuk mengatur waktu sebaik-baiknya, jalan-jalan, baca novel, nonton dvd."

[To deal with stress, I try to manage my time as best I can, go out, read novels, or watch DVDs.]

Participant 3

"Mengatasi stres dengan mendengarkan musik, shopping."

[I deal with stress by listening to music and going shopping.] 


\section{Participant 10}

orangtua."

"Upaya untuk mengatasi stres biasanya menceritakan semua masalah kepada

[I try to deal with stress by talking to my parents about what is bothering me.]

Participant 4

“Cara mengatasi mendengarkan orang mengaji dan melihat drama korea."

[One way I deal with stress is to listen to (recordings of) people reciting the Quran and watching Korean (TV) dramas.]

\section{Participant 5} sementara."

"Cara mengatasi stres dengan menyendiri dan menarik diri dari lingkungan untuk

[I deal with stress by going off by myself and leaving the situation for a while.]

Participant 6

It is a possibility that stress in young adults lead to destructive behaviour, such as suicide or drug use and may affect their academic performance. For this reason, it is important to understand the situations that lead to stress in young people. When being asked about this, most of the participants were familiar with stress and felt that it is common among university students in general.

"Stres jika tidak memiliki jalan keluar dari masalah yang dihadapi, bingung mau melakukan apa, tiba tiba bisa sakit maag (psikosomatis)." [Stress is when I can't find a way out of my problems, I'm confused about what to do; I might suddenly get a stomach ache (which is psychosomatic).]"

\section{Participant 4} orangtua."

"Terlalu banyak hal yang harus dikerjakan. .. tidak punya uang dan jauh dari

[Stress is when there are too many things to do. . . when you don't have money are far away from your parents.]

Participant 5

"Memiliki tekanan, banyak memiliki masalah yang sulit."

[It's when you're under pressure and have a lot of complicated problems.] 


\section{Participant 6}

For several of the participants, stress was strongly connected with time pressure and the volume of demands they faced. They were also aware of the potential for it to cause physical symptoms. One participant, for example, spoke repeatedly about loneliness as a source of stress.

"Kurang perhatian dari orangtua karena orangtua terlalu sibuk kerja. . . Merasa kesepian; tidak memiliki kedekatan dengan orangtua dan teman, merasa tidak punya sahabat dan terkadang merasa kalau teman-temannya jahat."

[My parents don't have much time for me because they are busy with work. I feel lonely. I don't have that closeness with my parents and friends. I felt like I don't have (real) friends and sometimes think my friends don't like me.]

\section{Participant 2}

"Jadi aku di rumah ya sendirian gitu. Kan kakakku sekarang sudah kerja juga, jadi aku merasa lebih kesepian lebih sendirian di rumah." [So I'm always home alone. My sister has a job now, so I'm lonely alone in the house.]

\section{Participant 2}

In traditional society, it was unusual for people to be alone, and being by oneself is still considered both undesirable and also inappropriate. Yet, abrupt social change, such as changes in employment, the time pressures, and travel distances involved in living in a very large city like Jakarta, have changed the pattern of many people's daily life. Consequently, loneliness is a problem for all age groups, and it is a source of stress that a majority of Indonesians are incompetent to overcome [52].

The participants in this study stated that they believe religion has made them more able to manage their emotions and stress and be more resilient. A number of them use prayer and recitation of Quranic verses as a way of relieving pressure that they feel. Some of them choose to become a member in religious groups, which they believed would support them during periods of stress. Being part of a group for these participants provided a source of support and reassurance because they felt that they would always have people to turn to who would stand by them. In some cases, however, the views of such groups were more rigid than the participants presumed could also become additional source of stress and unhappiness. In this sense, religious activity did not make the participants happy and, in fact, seemed to amplify the internal conflict they already had to struggle with.

For other participants, religion did not seem to help in managing their emotions and stress. They expected God to answer their prayers right away. When this did not come true, they tended to put blame on God for not helping them to overcome their difficult times. This expectation seemed to have developed over the course of their lives and reflects the way in which they, and many Indonesians, understand religious teachings. A number of the participants seem to consider prayer as a transaction with God where God was expected to fulfill the content of prayer in exchange for the act of praying. When this did not occur, the participants felt disappointed and at a loss. However, this situation was often interpreted as an 
indication that their prayers were inadequate or not performed correctly; the participants did not appear to question the validity of their expectation.

Interestingly, for some participants, several religious practices could also be a source of stress. For example, many of the female participants felt pressure to wear Islamic dress, which stands out in Indonesia because of the headscarf typically used by women in this context. This type of dress is associated with a number of social expectations. For example, people who are viewed as religious based on their manner of dress are also expected by others to limit social interactions with the opposite sex and not participate in romantic relationships. This view in Indonesian society in general and social disapproval experienced by the participants when their behavior did not conform to the expectations of others was also a source of stress and a constraint felt by many of the participants. Another participant set himself a target for his own religious practice based on the ideals and views of the more orthodox segment of the community, and experienced stress if he could not achieve his set targets for prayer, Quranic recitation, or other activities. These and other participants saw religious practice as a constraint that did not help them in overcoming or managing stress. Instead, they felt restricted by the requirements of religious practice, based either on their own interpretation or on the social norms of the community, which did not allow them to do the things they wanted to, in particular limiting their social interactions.

Like many Indonesians, these participants had been taught from childhood that praying, reciting the Quran and taking part in other religious activities should make them feel calmer and help find solutions for their problems. A few participants had tried to learn more about the meaning of religion and believed that God's help would come to them in some form. This encouraged them to find other ways to overcome and manage stress. In conclusion, most of participants were aware that religion may not be the only resource to cope with difficulty and that they could use other methods as companion that might also be effective.

As noted above, the practice of using prayer to ask God for what they need or want is common in Indonesia. For example, a type of group prayer that takes place in a public context, referred to as istighosah, is held when there is a drought, or the community is facing a threat or danger (from natural disaster, for example). A similar phenomenon was reported by some participants at a personal level. For one participant, being more mindful in her prayer and being more consistent in religious activities led to self-acceptance, and the participant felt grateful for what she had. This participant had tried other approaches to cope with stress yet choose religious practices as her coping strategy.

Other participants only use religious practice as a last resort when other strategies had not produced the result they hoped for. Interestingly, the participants expressed a belief that God always listened to their prayers, even when He did not answer them, which also reflects an aspect of religious belief that is generally held in Indonesia.

\section{References}

[1] Fee, L. K. The construction of Malay identity across nations: Malaysia, Singapore, and Indonesia. Bijdragen tot de Taal-, Land- en Volkenkunde, 157(4), 861-879. (2001).

[2] Picard, M., \& Madinier, R. The politics of religion in Indonesia: Syncretism, orthodoxy, and religious contention in Java and Bali: Routledge (2011).

[3] Burhani, A. N. Defining Indonesian Islam: an examination of the construction of the national Islamic identity of traditionalist and modernist Muslims (pp. 25-48): Amsterdam: University of Amsterdam Press. (2013).

[4] Dewan Bahasa dan Pustaka. Kamus Bahasa Melayu Brunei. Bandar Seri Begawan: Dewan Bahasa dan Pustaka. (1991). 
[5] Sukandar, U. Doa-Doa yang Menyembuhkan. Yogyakarta, Indonesia: Selingkar Rumah Idea Pustaka. (2011).

[6] Suriana, N. Doa Penenang Hati. Depok, Indonesia: Rumah Ide. (2011).

[7] Wieringa, E. P. Timothy Daniels: Islamic spectrum in Java. Der Islam(1), 211. doi: 10.1515/islam-2012-0011. (2012).

[8] Woodward, M. The Slametan: Textual Knowledge and Ritual Performance in Yogyakarta Java, Indonesia and Islam (pp. 113-136): Springer. (2011).

[9] Fanany, R., \& Fanany, I. Post-disaster coping in Aceh: Sociocultural factors and emotional response. When Culture Impacts Health, 225. (2013).

[10] Heiduk, F. State disintegration and power politics in post-Suharto Indonesia. Third World Quarterly, 35(2), 300-315. (2014).

[11] Bush, R. Regional sharia regulations in Indonesia: Anomaly or symptom? In Expressing Islam: Religious Life and Politics in Indonesia, edited by Greg Fealy and Sally White. Singapore: Institute of Southeast Asian Studies), 174-191. (2008).

[12] Rinaldo, R. Envisioning the Nation: Women Activists, Religion and the Public Sphere in Indonesia. Social Forces (4), 1781. (2008)

[13] Hofstede, G. Culture's Consequences: Comparing Values, Behaviors, Institutions and Organizations Across Nations: SAGE. (2001).

[14] Venardos, A. M. Islamic banking \& finance in South-East Asia: Its development \& future (Vol. 6): World Scientific. (2012).

[15] Wicaksono, B., \& Georgina, R. Ini Tempat Hiburan Malam Jakarta yang Tutup Selama Ramadan. Retrieved 11 June 2015 http://www.viva.co.id/ramadhan2015/news/read/ 6369 08/initempat-hiburan-malam-jakarta-yangtutup- selama-ramadan. (2015).

[16] Tribunnews. Lawan' Kicauan Menag, Selama Puasa Restoran di Banjarmasin Wajib Tutup Siang Hari. Retrieved 19 June, 2015, from http://www.tribunnews.com/ramadan/2015/06/19 /lawa nkicauan-menag-selama-puasa-restorandi- banjarmasin-wajib-tutup-siang-hari. (2015).

[17] Ngazis, A.N., \& Maulida, A. MUI Usul Perda Larangan Jual Makanan Selama Ramadhan. Retrieved 10June, 2015, from http://metro.news.viva.co.id/news/read/636605- mui- usul-perdalarangan-jual-makanan-selamaramadhan. (2015).

[18] Cammack, M. E., \& Feener, R. M. The Islamic legal system in Indonesia. Pac. Rim L. \& Pol'y J., 21, 13 . (2012).

[19] Joll, C. M. Local and global Islams in Southeast Asia: Historical and anthropological perspectives. Social Science and Knowledge in a Globalising World, 219-242. (2012).

[20] Katz, M. H. Prayer in Islamic thought and practice: Cambridge University Press (2013).

[21] Giorgi, A. The descriptive phenomenological method in psychology: A modified Husserlian approach: Duquesne University Press. (2009).

[22] Eliassen, A. H. Religious coping and depression in young adulthood: Effects of global stress exposure and pre-teenage religious service attendance. Review of Religious Research, 55(3), 413-433. doi: 10.1007/s13644-013-0110-9. (2013).

[23] Aldwin, C. M. Stress, coping, and development: An integrative perspective. (2007).

[24] Nolen-Hoeksema, S., Parker, L. E., \& Larson, J. Ruminative coping with depressed mood following loss. Journal of personality and social psychology, 67(1), 92. (1994).

[25] Moskowitz, J. T., Hult, J. R., Bussolari, C., \& Acree, M. What works in coping with HIV? A meta- analysis with implications for coping with serious illness: American Psychological Association. (2009).

[26] Pargament, K. I. The psychology of religion and coping: theory, research, practice: New York: Guilford Press, c1997. (1997).

[27] Pargament, K. I. The psychology of religion and coping: Theory, research, practice: Guilford Press. (2001). 
[28] Pargament, K. I., Koenig, H. G., \& Perez, L. M. The many methods of religious coping: Development and initial validation of the RCOPE. Journal of clinical psychology, 56(4), 519543. (2000).

[29] Pargament, K. I. The psychology of religion and coping: theory, research, practice: New York: Guilford Press, c1997. (1997).

[30] McIntosh, D. N., Silver, R. C., \& Wortman, C. B. Religion's role in adjustment to a negative life event: coping with the loss of a child. Journal of personality and social psychology (4), 812. (1993).

[31] Inglehart, R. Culture shift in advanced industrial society: Princeton University Press. (1990).

[32] Myers, D. G. The funds, friends, and faith of happy people. American Psychologist, 55(1), 56. (2000).

[33] Frankel, B. G., \& Hewitt, W. Religion and well- being among Canadian university students: The role of faith groups on campus. Journal for the Scientific Study of Religion, 62-73. (1994).

[34] Veenhoven, R. World database of happiness: Correlates of happiness: 7,837 findings from 603 studies in 69 nations 1911-1994, Vols. 1-3. Rotterdam. (1994).

[35] Mookerjee, R., \& Beron, K. Gender, religion and happiness. The Journal of SocioEconomics, 34(5), 674-685. (2005).

[36] Abdel-Khalek, A. M. Happiness, health, and religiosity: significant relations. Mental Health, Religion \& Culture, 9(1), 85-97. (2006).

[37] Poloma, M. M., \& Pendleton, B. F. Exploring types of prayer and quality of life: A research note. Review of Religious Research, 46- 53. (1989).

[38] Poloma, M. M., \& Pendleton, B. F. Religious domains and general well-being. Social Indicators Research, 22(3), 255-276. (1990).

[39] Poloma, M. M., \& Pendleton, B. F. The effects of prayer and prayer experiences on measures of general well-being. Journal of Psychology and Theology. (1991).

[40] Brinkerhoff, M. B., \& Mackie, M. M. Casting off the bonds of organized religion: A religiouscareers approach to the study of apostasy. Review of Religious Research, 235- 258. (1993).

[41] Abdel-Khalek, A. M., \& Naceur, F. Religiosity and its association with positive and negative emotions among college students from Algeria. Mental Health, Religion \& Culture, 10(2), 159170. (2007).

[42] Janssen, F., Bänziger, S., Dezutter, J., \& Hutsebaut, D. Religion and mental health: Aspects of the relation between religious measures and positive and negative mental health. Archive for the Psychology of Religion, 27(1), 19-44. (2005).

[43] Lewis, C. A., \& Cruise, S. M. Religion and happiness: Consensus, contradictions, comments and concerns. Mental Health, Religion and Culture, 9(03), 213-225. (2006).

[44] Francis, L. J., \& Stubbs, M. T. Measuring attitudes towards Christianity: From childhood into adulthood. Personality and Individual differences, 8(5), 741-743. (1987).

[45] Argyle, M., Martin, M., \& Crossland, J. Happiness as a function of personality and social encounters. Recent advances in social psychology: An international perspective, 189-203. (1989).

[46] Joseph, S., \& Lewis, C. A. The depression- happiness scale: Reliability and validity of a bipolar self-report scale. Journal of Clinical Psychology, 54(4), 537-544. (1998).

[47] Lewis, C. A., \& Cruise, S. M. Religion and happiness: Consensus, contradictions, comments and concerns. Mental Health, Religion and Culture, 9(03), 213-225. (2006).

[48] Lewis, C. A. Church attendance and happiness among Northern Irish undergraduate students: No association. Pastoral Psychology, 50(3), 191-195. (2002).

[49] Lewis, C. A., Maltby, J., \& Day, L. Religious orientation, religious coping and happiness among UK adults. Personality and Individual differences, 38(5), 1193-1202. (2005).

[50] Lewis, C. A., \& Cruise, S. M. Religion and happiness: Consensus, contradictions, comments and concerns. Mental Health, Religion and Culture, 9(03), 213-225. (2006). 
[51] Schneider, A., Mertes, C., Tatem, A., Tan, B., SullaMenashe, D., Graves, S., Rollo, J. A new urban landscape in East-Southeast Asia, 2000- 2010. Environmental Research Letters, 10(3), 034002. (2015).

[52] Purwono, U., \& French, D. C. Depression and its relation to loneliness and religiosity in Indonesian Muslim adolescents. Mental Health, Religion \& Culture, 19(3), 218-228. (2016). 